\title{
INVAZIVNE BILJNE VRSTE I EKOLOŠKI ČIMBENICI KOJI UTJEČU NA NJIHOVO ŠIRENJE NA PODRUČJU SPOMENIKA PRIRODE "OBRENOVAČKI ZABRAN" (SREDIŠNJA SRBIJA)
}

\section{INVASIVE PLANT SPECIES AND ECOLOGICAL FACTORS INFLUENCING THE SPREADING IN THE AREA OF THE OBRENOVAČKI ZABRAN NATURE MONUMENT (CENTRAL SERBIA)}

Jovana PETROVIĆ1, Srećko ĆURČIĆ ${ }^{2}$ Nenad STAVRETOVIĆ ${ }^{1}$

\begin{abstract}
Sažetak
Osnovni cilj i zadatak provedenog istraživanja bio je utvrditi prisutnost invazivnih biljnih vrsta na području zaštićenog prirodnog dobra Spomenik prirode „Obrenovački Zabran“ (središnja Srbija). Istraživanja flore i vegetacije šume Obrenovački Zabran rađena su tijekom više vegetacijskih sezona od ožujka 2009. do studenog 2013. godine. Bogatstvo flore ogleda se kroz prisutnost 163 biljne vrste koje su zabilježene na području Obrenovačkog Zabrana. Od ukupnog broja zabilježenih biljnih vrsta, 24 taksona su označena kao invazivne vrste, što čini 14,72\% ukupne flore Zabranske šume. Među njima je prisutno 6 drvenastih i 18 zeljastih biljnih vrsta. Duž čitavog nasipa u Obrenovačkom Zabranu evidentirane su vrste Asclepias syriaca i Amorpha fruticosa s velikom pokrovnošću i brojnošću. Ove dvije vrste formiraju rub šume ka rijeci Savi, tako da su potisnule gotovo sve druge biljne vrste iz kata žbunja, s tendencijom da potisnu i već sada oskudnu prizemnu vegetaciju. Svjetlost i temperatura su ekološki čimbenici koji posebno pogoduju razvoju i širenju invazivnih biljaka u Obrenovačkom Zabranu, a koji su najizraženiji u području nasipa. Zbog toga i zbog izraženog antropogenog utjecaja, tj. velike frekvencije korisnika, invazivne vrste biljaka su unešene i prisutne na području Zabrana. Od ukupnog broja zabilježenih invazivnih vrsta biljaka, najveći broj pripada porodici Asteraceae (9 vrsta), zatim porodicama Poaceae i Fabaceae (s po 2 vrste), dok su ostale porodice zastupljene sa po jednom vrstom.

Rezultati istraživanja trebaju dati osnovu za razvoj strategije za praćenje stanja i planiranje mjera za suzbijanje neželjenih biljnih vrsta radi zaštite autohtone flore. Samo pažljivo i odgovorno upravljanje prirodnim dobrom omogućit će da se broj invazivnih biljnih vrsta održi na postojećoj razini.
\end{abstract}

KLJUČNE RIJEČI: Rijeka Sava, Obrenovački Zabran, invazivne vrste, zaštita okoliša, zaštita prirode

\footnotetext{
${ }^{1}$ Dr. sc. Jovana Petrović, dr. sc. Nenad Stavretović, Sveučilište u Beogradu - Šumarski fakultet, Kneza Višeslava 1, 11000 Beograd, Srbija

2 Dr. sc. Srećko Ćurčić, Institut za zoologiju, Sveučilište u Beogradu - Biološki fakultet, Studentski trg 16, 11000 Beograd, Srbija

Corresponding author: jovana.stevanovic@sfb.bg.ac.rs
} 


\section{UVOD}

\section{INTRODUCTION}

Ekološki utjecaj alohtonih (introduciranih) biljnih vrsta i mehanizmi njihovog brzog širenja u biljnim zajednicama istraživani su i predstavljeni u mnogim radovima (Elton 1958., Drake i dr. 1989., Di Castri i dr. 1990., Šilc i dr. 2012., Obratov-Petković i dr. 2013.), a alohtone biljne vrste nisu uvijek i invazivne. Prema Međunarodnoj uniji za zaštitu prirode (IUCN 2011.), invazivne biljne vrste se definiraju kao one koje ugrožavaju bioraznolikost određenog područja na genskoj, specijskoj i ekosustavnoj razini. Prema podacima IUCN (2011.), u Europi je trenutno zabilježeno ukupno 10.961 taksona alohtonih vrsta biljaka, a za 10-15\% se procjenjuje da imaju negativne ekološke i gospodarstvene posljedice. Prema istom izvoru, štete uvjetovane od strane invazivnih vrsta, kao i neophodne mjere kontrole, koštaju Europu 12,7 milijardi EUR godišnje. Gradove kao središta introdukcije i širenja invazivnih vrsta navode pojedini autori (Kowarik 1995., Godefroid i Koedam 2007.). Osim što ugrožavaju autohtonu bioraznolikost, sve je veći broj invazivnih vrsta koje ozbiljno ugrožavaju ljudsko zdravlje (Stavretović i dr. 2010.).

Šuma Obrenovački Zabran nalazi se na području općine Obrenovac, koja administrativno pripada Gradu Beogradu. Šuma je od centra Obrenovca udaljena zračnom linijom oko $1,5 \mathrm{~km}$ u smjeru istoka, odnosno $12 \mathrm{~km}$ jugozapadno od predgrađa Beograda. Posebna vrijednost Zabrana ogleda se u tome, što u široj okolici općinskog centra nema većih površina pod visokom autohtonom vegetacijom. Vegetacija u forlandu rijeka Save i Kolubare u prosjeku je u lošem stanju i zahvaća znatno manje površine uslijed izgradnje naselja, infrastrukturnih objekata i širenja poljoprivrednih površina. Zbog svojih vrijednosti ispitivani lokalitet je, na temelju Zakona o zaštiti prirode Srbije („Službeni glasnik RS“, br. 36/09, 88/10 i 91/10), predložen za zaštitu kao prirodno dobro - Spomenik prirode botaničkog karaktera „Obrenovački Zabran“ III kategorije.

Šuma Obrenovački Zabran je prostor masovnog okupljanja ljudi, a planiranje i uređenje takvog područja podrazumijeva održavanje autohtone vegetacije, ali nerijetko i unošenje i širenje alohtone (Petrović i dr. 2013.). Na taj način čovjek slučajnom ili češće namjernom introdukcijom alohtonih vrsta čini prvi korak u procesu invazije (Stevanović i dr. 2009.).

Provedena istraživanja invazivnih biljnih vrsta na području zaštićenog prirodnog dobra Obrenovački Zabran omogućila su definiranje stanja područja i utvrđivanje u kojoj su mjeri invazivne biljne vrste zastupljene, kako bi se u budućnosti mogla pratiti njihova stanja i tendencije. Također provedena istraživanja daju podatke o značajnim ekološkim čimbenicima koji utječu na formiranje flore područja, ali ukazuju i na utjecaj neofita na ostale prisutne biljke. Rezul- tati istraživanja trebali bi pružiti temelj za razvoj strategije praćenje stanja i planiranja mjera za suzbijanje neželjenih vrsta radi zaštite autohtone vegetacije.

\section{MATERIJAL I METODE MATERIAL AND METHODS}

Obrenovački Zabran nalazi se u središnjoj Srbiji. Ukupna površina zaštićenog prirodnog dobra iznosi 4.777,18 ha. Nadmorska visina na zaštićenom prostoru kreće se u rasponu 73-77,5 m. Površine u granicama zaštićenog prirodnog dobra su najvećim dijelom u državnom vlasništvu kojim gospodari Javno poduzeće „Srbijašume“, Šumsko gazdinstvo „Beograd“, Gazdinska jedinica „Košutnjačke šume“ (Studij zaštite: Spomenik prirode „Obrenovački Zabran”, 2011.),

Područje Obrenovačkog Zabrana, zajedno sa svojom okolicom, u vegetacijskom smislu pripada potencijalnoj vegetaciji sveze mezofilnih nizijskih poplavnih lužnjakovih šuma - Quercion roboris Tüxen 1931 (Stevanović 1995). Prema klasifikaciji staništa (Lakušić i dr. 2005), ovaj tip staništa u Republici Srbiji se označava kao „mješovite šume poljskog jasena (Fraxinus angustifolia L.) i lužnjaka (Quercus robur L.) duž velikih rijeka". Na području Zabrana ustanovljene sljedeće su sveze i zajednice (Tomić 1986.): sveza Alno-Quercion roboris Ht. 1938. i zajednice Fraxino-Quercetum roboris Rudski 1949. i Carpino-Fraxino-Quercetum roboris B. Jov. et Domazet 1978., sveza Salicion albae Soó 1940. i zajednica Salicetum albae Issler 1926., sveza Lemnion W. Koch et Tx. 1954. i zajednica Lemnetum minoris Müller et Görs 1960., kao i sveza Bidention tripartiti Nordh. 1940. i zajednica Bidentetum tripartitae s. l. (Lakušić 1993.). U fitocenološkom smislu, autohtona šuma lužnjaka i jasena (Fraxino-Quercetum roboris) obuhvaća najveće površine Zabrana. Uslijed antropogenih utjecaja (sječe i raskidanja sklopa) na čitavom prostoru ove zajednice jasen je postao dominantna vrsta. U katu drveća je, osim edifikatora, zabilježena i prisutnost veza (Ulmus effusa Willd.), poljskog bresta (Ulmus minor Mill.), bijele topole (Populus alba L.), klena (Acer campestre L.) i drugih vrsta, a od alohtone flore drveća treba spomenuti plantažno unešeni američki jasen (Fraxinus americana L.) i euroameričku topolu [Populus $\mathrm{x}$ euramericana (Dode) Guinier], te sekundarno dosta proširene invazivne vrste bagremac (Amorpha fruticosa L.) i pajavac (Acer negundo L.) (Studij zaštite: Spomenik prirode „Obrenovački Zabran“, 2011.).

Terenska istraživanja flore i vegetacije Obrenovačkog Zabrana rađena su tijekom više vegetacijskih sezona od ožujka 2009. do studenog 2013. godine. Determinacija biljaka obavljena je prema sljedećim literaturnim izvorima: Jávorka i Csapody (1934.), Tutin i dr. (1964-1980.), Josifović i dr. (1970-1986.), Kojić (1990.), Šarić (1991.) i Stavretović (2008.). 
Analiza strukture i florističkog sastava biljaka obavljena je po standardnoj fitocenološkoj metodi (Braun-Blanquet 1964.). Svi fitocenološki snimci (ukupno 24) skladišteni su u bazu programa za vegetaciju TURBOVEG (Hennekens i Schaminée 2001) u bazu podataka. Na setu podataka urađena je klasterska analiza u programu PC-ORD 5 (McCune i Mefford 1999.), pri čemu je korišten Relativni Sørensenov indeks kao mjera distance i algoritam Flexibile Beta za konstrukciju dendrograma s parametrom $\beta=-0.25$. Za utvrđivanje optimalnog broja klastera u odnosu na broj

Tablica 1. Pregled invazivnih biljnih vrsta na području Spomenika prirode „Obrenovački Zabran”.

Table 1. List of invasive plant species in the Obrenovački Zabran Nature Monument.

\begin{tabular}{|c|c|c|c|c|}
\hline Redni broj & Znanstveni naziv & Engleski naziv & Porodica & Prirodno stanište \\
\hline Ordinal no. & Scientific name & English common name & Family & Native range \\
\hline 1. & Acer negundo $\mathrm{L}$. & Ash-leaf Maple & Aceraceae & $\begin{array}{l}\text { Sjeverna Amerika } \\
\text { North America }\end{array}$ \\
\hline 2. & Ailanthus altissima (Mill.) Swingle & Tree-of-Heaven & Simaroubaceae & $\begin{array}{l}\text { Azija } \\
\text { Asia }\end{array}$ \\
\hline 3. & Aster lanceolatus Willd. & White Panicle & Asteraceae & $\begin{array}{c}\text { Sjeverna Amerika } \\
\text { North America }\end{array}$ \\
\hline 4. & Amaranthus retroflexus $\mathrm{L}$. & Common Amaranth & Amaranthaceae & $\begin{array}{l}\text { Sjeverna Amerika } \\
\text { North America }\end{array}$ \\
\hline 5. & Ambrosia artemisiifolia L. & Common Ragweed & Asteraceae & $\begin{array}{l}\text { Sjeverna Amerika } \\
\text { North America }\end{array}$ \\
\hline 6. & Amorpha fruticosa $\mathrm{L}$. & False Indigo & Fabaceae & $\begin{array}{l}\text { Sjeverna Amerika } \\
\text { North America }\end{array}$ \\
\hline 7. & Aristolochia clematitis L. & Birthwort & Aristolochiaceae & $\begin{array}{l}\text { južna Europa i Mediteran } \\
\text { South Europe and Mediterranean }\end{array}$ \\
\hline 8. & Artemisia vulgaris $\mathrm{L}$. & Bulwand Wormwood & Asteraceae & $\begin{array}{l}\text { Sjeverna Amerika } \\
\text { North America }\end{array}$ \\
\hline 9. & Asclepias syriaca L. & Common Milkweed & Asclepiadaceae & $\begin{array}{l}\text { Sjeverna Amerika } \\
\text { North America }\end{array}$ \\
\hline 10. & Bidens frondosus $\mathrm{L}$. & Devil's Beggartick & Asteraceae & $\begin{array}{l}\text { Sjeverna Amerika } \\
\text { North America }\end{array}$ \\
\hline 11. & Cichorium intybus L. & Chicory/Blue Sailors & Asteraceae & $\begin{array}{l}\text { Euroazija } \\
\text { Eurasia }\end{array}$ \\
\hline 12. & Conyza canadensis (L.) Cronquist & Canadian Fleabane & Asteraceae & $\begin{array}{l}\text { Sjeverna Amerika } \\
\text { North America }\end{array}$ \\
\hline 13. & Echinocystis lobata (Michx.) Torrey \& Gray & Wild Cucumber & Cucurbitaceae & $\begin{array}{l}\text { Sjeverna Amerika } \\
\text { North America }\end{array}$ \\
\hline 14. & Echinochloa crus-galli (L.) Beauv. & Barnyardgrass & Poaceae & $\begin{array}{l}\text { Euroazija } \\
\text { Eurasia }\end{array}$ \\
\hline 15. & Erigeron annuus (L.) Pers. & Eastern Daisy Fleabane & Asteraceae & $\begin{array}{l}\text { Sjeverna Amerika } \\
\text { North America }\end{array}$ \\
\hline 16. & Inula britannica L. & Meadow Fleabane & Asteraceae & $\begin{array}{l}\text { Euroazija } \\
\text { Eurasia }\end{array}$ \\
\hline 17. & Parthenocissus quinquefolia (L.) Planch. & Virginia Creeper & Vitaceae & $\begin{array}{l}\text { Sjeverna Amerika } \\
\text { North America }\end{array}$ \\
\hline 18. & Picris echioides $\mathrm{L}$. & Bristly Oxtongue & Asteraceae & $\begin{array}{l}\text { južna Europa i sjeverna Afrika } \\
\text { South Europe and North Africa }\end{array}$ \\
\hline 19. & Polygonum aviculare $\mathrm{L}$. & Common Knotgrass/Doorweed & Polygonaceae & $\begin{array}{l}\text { tropska regija } \\
\text { Tropical belt }\end{array}$ \\
\hline 20. & Portulaca oleracea L. & Common Purslane & Portulacaceae & $\begin{array}{l}\text { sjeverna Afrika } \\
\text { North Africa }\end{array}$ \\
\hline 21. & Robinia pseudoacacia L. & Black Locust & Fabaceae & $\begin{array}{l}\text { Sjeverna Amerika } \\
\text { North America }\end{array}$ \\
\hline 22. & Rubus caesius $\mathrm{L}$. & Dewberry & Rosaceae & $\begin{array}{l}\text { Euroazija } \\
\text { Eurasia }\end{array}$ \\
\hline 23. & Sorghum halepense (L.) Pers. & Johnson Grass & Poaceae & $\begin{array}{c}\text { Mediteran i Azija } \\
\text { Mediterranean and Asia }\end{array}$ \\
\hline 24. & Urtica dioica L. & Common Nettle & Urticaceae & $\begin{array}{l}\text { Euroazija } \\
\text { Eurasia }\end{array}$ \\
\hline
\end{tabular}


vrsta koje imaju visoku vezanost za određeni klaster, upotrijebljen je OptimClass metod, pri čemu je korišten parametar 50 (Tichý i dr. 2010.). Veze između klastera i vrijednosti ekoloških indikatora analizirane su ordinacijskom DCA analizom u programu JUICE 7.0 (Tichý 2002.) i programskom okruženju R pomoću paketa Vegan (Oksanen i dr. 2013.), pri čemu su vrijednosti pokrovnosti transformirane korjenovanjem. Prosjeci ekoloških indikatorskih vrijednosti biljnih vrsta izračunati za svaki snimak pasivno su postavljeni na ordinacijski grafikon kao dodatne srednje varijable.

Za utvrđivanje prisutnosti invazivnih vrsta biljaka korišteni su podaci o naturalizaciji vrsta u srednjoj Europi iz tri relevantne „on line” baze podataka: Popis invazivnih vrsta za područje Europe (Delivering Alien Invasive Species Inventories for Europe, European Invasive Alien Species Gateway, http://www.europe-aliens.org/), Crna lista i lista za praćenje Švicarske komisije za očuvanje biljnih vrsta (CPS SKEW Schwarze Liste und Watch-Liste, Invasive gebietsfremde Pflanzen, http://www.cps-skew.ch/) i Globalna baza podataka o invazivnim vrstama (Global Invasive Species Database, http://www.issg.org/database/). Također su korišteni i preliminarni popis invazivnih vrsta u Republici Srbiji (Lazarevići dr. 2012.), kao i liste autora Vrbničanin i dr. (2004.), Kaufman i Kaufman (2007.) i Boršić i dr. (2008.).

\section{REZULTATI}

\section{RESULTS}

Na području Obrenovačkog Zabrana zabilježene su ukupno 163 biljne vrste. Od ukupnog broja zabilježenih biljnih vrsta, 24 taksona se svrstava u invazivne vrste, što čini $14,72 \%$ od ukupne flore Spomenika prirode „Obrenovački Zabran“" (Tablica 1). Među njima je prisutno 6 drvenastih i 18 zeljastih biljnih vrsta.

Od ukupnog broja zabilježenih invazivnih vrsta biljaka, najveći broj pripada porodici Asteraceae (9 vrsta), te porodicama Poaceae i Fabaceae (s po 2 vrste), dok su ostale porodice zastupljene sa po jednom vrstom.

Duž čitavog nasipa evidentirane su vrste Asclepias syriaca L. i A. fruticosa s velikom pokrovnošću i brojnošću. Ove dvije vrste formiraju rub šume ka rijeci Savi, tako da su potisnule gotovo sve druge biljne vrste iz kata žbunja, $s$ tendencijom da potisnu i već sada oskudnu prizemnu floru. Otkos se ne odnosi s površine, a osnov stabljike i korjenov sustav nalaze se ispod noža na kosačici, tako da se same vrste ne uklanjaju u potpunosti operacijom košenja i lako se samoobnavljaju. Osim toga, samo na trim stazi na nasipu zabilježene su i vrste kojima više odgovaraju mezofilna staništa [Bidens frondosus L., Conyza canadensis (L.) Cronquist, Echinochloa crus-galli (L.) Beauv., Sorghum halepense (L.) Pers.]. Vrsta Aster lanceolatus Willd. je s većom pokrovnošću zabilježena na površini u izletištu, gdje se javlja za- jedno s vrstom Rubus caesius L. Vrsta Erigeron annuus (L.) Pers. je prisutna na čitavom području urbane šume Obrenovački Zabran, ali s malobrojnim i pojedinačnim individuama. Samo na trim stazi na nasipu zabilježena je vrsta Cichorium intybus L., koja podnosi suhe i osunčane terene. $\mathrm{Na}$ trim stazi koja je trasirana kroz šumu, među zabilježenim korovnim vrstama, uočena je izražena prisutnost vrsta R. caesius i Urtica dioica L. Među invazivnim vrstama koje su prisutne na obje istraživane trim staze, svojom pokrovnošću ističe se vrsta Polygonum aviculare L.

Od ukupnog broja zabilježenih biljnih vrsta, 26 (16,14\%) su alergene vrste: Agrostis stolonifera L., Alopecurus pratensis L., Amaranthus retroflexus L., Ambrosia artemisiifolia L., Arrenatherum elatius L., Bromus sterilis L., Chenopodium album L., C. intybus, Cynodon dactylon (L.) Pers, Dactylis glomerata L., Festuca arundinacea Schreb., E. crus-galli, Hedera helix L., Hordeum murinum L., Lolium perenne L., Plantago lanceolata L., Plantago major L., Poa pratensis, . aviculare, P. alba, Rumex obtusifolius L., Setaria viridis (L.) P. Beauv., Sorghum halepense (L.) Pers, Stellaria media (L.) Will., Taraxacum officinale F.H.Wigg i U. dioica. Među prisutnim alergenim vrstama, mnoge su i invazivne. Alergene biljke koje se ističu svojom pokrovnošću su $L$. perenne, $T$. officinale, $U$. dioica i A. artemisiifolia.

Ordinacijska DCA analiza pokazala je da najveći utjecaj na floru i vegetaciju Obrenovačkog Zabrana imaju svjetlost i vlaga (Slika 1). Također, kao značajni čimbenici koji utječu na floru i vegetaciju ispitivanog lokaliteta izdvojili su se i

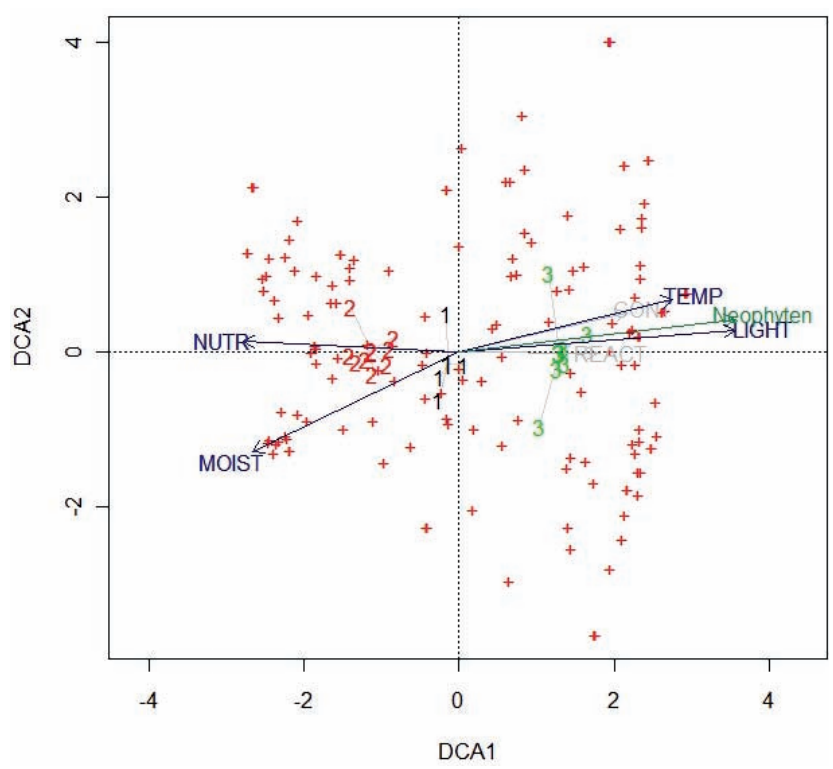

Slika 1. Dijagram DCA ordinacije baze podataka s pasivno projektiranim vrijednostima varijabli ekoloških indikatora (NUTR - ekološki indikator za plodnost zemljišta, TEMP - ekološki indikator za temperaturu, MOIST - ekološki indikator za vlažnost, LIGHT - ekološki indikator za svjetlost). Fig. 1. DCA ordination diagram of the whole dataset with passively projected explanatory variables (NUTR - ecological indicator for soil fertility, TEMP - ecological indicator for temperature, MOIST - ecological indicator for moisture, LIGHT - ecological indicator for light). 
gradijenti za plodnost zemljišta (sadržaj hranljivih materija) i temperaturu. Na najvlažnijim staništima razvija se vegetacija koju karakterizira dominacijom vrsta A. stolonifera, R. caesius, Prunella vulgaris L., $P$. aviculare, L. perenne, A. lanceolatus i Glechoma hederacea L. Značajan antropogeni utjecaj ogleda se kroz prisutnost dominantne vrste Poa annua L., ali i konstantnih vrsta T. officinale i P. major. $\mathrm{Na}$ vlažnim staništima na dubljem plodnijem zemljištu razvija se tipična šumska vegetacija s dominacijom vrsta Viola odorata L., Brachypodium sylvaticum (Huds.) P. Beauv., Carex divulsa Stokes, U. dioica, Geranium robertianum L., Chaerophyllum temulum L., Geum urbanum L., H. helix, Rumex sanguineus L. i Potentilla reptans L. Svjetlost i temperatura su ekološki čimbenici koji uvjetuju razvoj vegetacije na nasipu u Obrenovačkom Zabranu s dominacijom vrsta A. syriaca, C. dactylon, A. elatius, Lactuca serriola L., Bromus hordaceus L., C. intybus, Lotus corniculatus L., Galium mollugo L., C. canadensis, Achillea millefolium L., S. halepense i E. crus-galli. Ordinacijska analiza pokazala je da čimbenik prisutnosti neofita značajno utječe na floru i vegetaciju Obrenovačkog Zabrana. Neofite najveći utjecaj ostvaruju na toplim i osvjetljenim staništima, tj. na nasipu (Slika 1, klaster 3). Spomenuto je evidentno i na osnovi prisutnosti dominantnih, konstantnih i dijagnostičkih vrsta, među kojima je velik broj invazivnih (A. syriaca, C. intybus, C. canadensis, S. halepense, E. crus-galli, A. fruticosa, P. aviculare, Inula britannica L., A. artemisiifolia).

\section{RASPRAVA}

\section{DISCUSSION}

Tijekom 2002. godine na inicijativu poduzeća Ekofond Obrenovac, započeti su radovi na formiranju rekreativnog područja u Zabranskoj šumi (osnovna mreža staza, sanitarne sječe). Idućih godina šuma je opremljena drvenim klupama, tablicama, kantama za smeće, kolnim pristupom šumi, a uređene su i dvije trim staze (jedna koja ide kroz šumu i druga na nasipu) (Krstić 2011.).

$\mathrm{Na}$ istraživanim trim stazama na području zaštićenog dobra Obrenovački Zabran, biljne vrste E. annuus i A. fruticosa zabilježene su na svim fitocenološkim snimcima. $\mathrm{U}$ više od polovice fitocenoloških snimaka prisutne su sljedeće vrste: L. perenne, P. pratensis, B. sterilis, Elymus repens (L.) Gould, P. major, Aristolochia clematitis L., P. reptans, U. dioica, T. officinale, P. vulgaris, G. hederacea, Lysimachia nummularia L., A. lanceolatus, Vincetoxicum hirundinaria Medik., Symphytum officinale L., G. urbanum, Rumex conglomeratus Murray, P. lanceolata, B. sylvaticum, Ajuga reptans $\mathrm{L}$. i $R$. caesius. Značajna prisutnost spomenutih vrsta kao ruderalnih elemenata flore iznosi se i u Studiji zaštite: Spomenik prirode „Obrenovački Zabran“ (2011) i tumači kao posljedica jako izraženog i stalno prisutnog antropogenog utjecaja.
Iz grupe klijanaca drvenastih vrsta ističu se biljne vrste $A$. fruticosa i R. caesius. A. fruticosa na trim stazi trasiranoj kroz šumu zabilježena je s malim vrijednostima merenih parametara (ocene $r,+$ ), dok je njena pokrovnost i brojnost na trim stazi na nasipu nešto veća, što se podudara s rezultatima istraživanja rekreacijskih površina Beograda (Stevanović i dr. 2009.). R. caesius je prisutan na svim snimcima na trim stazi u šumi, dok se na jednoj površini u izletištu javlja s većom pokrovnošću. Prisutnost vrste $R$. caesius na urbanim travnjacima ukazuje na njihovu veliku zakorovljenost, odnosno na odsutnost mjera njege i održavanja (Stavretović 2002.) ili na njihovo nepravovremeno i neadekvatno provođenje.

Među zabilježenim invazivnim vrstama posebno se ističe prisutnost A. fruticosa, A. syriaca, A. artemisifolia, C. intybus, R. caesius i U. dioica, kao i agresivnih korova C. dactylon i P. aviculare. U Studiji zaštite: Spomenik prirode „Obrenovački Zabran” (2011.) također se navode spomenute vrsta biljaka. Witting (2004.) iznosi da su P. aviculare i $U$. dioica među korovima koji se najčešće javljaju u urbanim sredinama s visokom pokrovnošću. Samo na trim stazi na nasipu zabilježene su vrste $C$. intybus i $C$. dactylon jer podnose suhe i osunčane terene. Na trim stazi koja je trasirana kroz šumu među zabilježenim korovnim vrstama, uočena je brojna prisutnost vrsta $R$. caesius i $U$. dioica. Razlog su uvjeti sredine koji vladaju u šumskom sklopu gdje je locirana trim staza, a koji pogoduju razvoju ovih vrsta. Među alergenim vrstama biljaka prisutnošću se ističu $L$. perenne, T. officinale, U. dioica i A. artemisiifolia. Pelud trave $L$. perenne ubraja se među pet najčešćih uzročnika alergijske manifestacije izazvane peludom, koja je još više naglašena u kombinaciji s drugim alergenim travama (Igić 2012). Ekstrakt T. officinale izaziva alergijski kontaktni dermatitis (Dawe i dr. 1996., Paulsen i dr. 1998., Mark i dr. 1999, Jovanović i dr. 2004.). Kopriva je jedna od alergenih biljnih vrsta koja alergijsku reakciju kod ljudi izaziva dodirom, lomljenjem ili gnječenjem (Di Tomaso 2004.). Ambrozija je jedan od najznačajnijih i najjačih alergena, koji zauzima važno mjesto među uzročnicima alergijskih bolesti s kojima je u posljednje vrijeme stanovništvo u većini zemalja sve više suočeno (Janjić i dr. 2011.). Najveći broj alergenih vrsta zabilježenih na trim stazama na lokalitetu Obrenovački Zabran su peludnoalergijske vrste, dok je znatno manje onih koje negativno djelovanje na korisnike ostvaruju kao kontaktni ili fotokontaktni dermatitis.

Ordinacijska analiza pokazala je da su svjetlost i temperatura čimbenici koji najviše utječu na razvoj neofita, što je evidentno na nasipu u Obrenovačkom Zabranu, gdje su invazivne vrste u velikom broju prisutne među dijagnostičkim, dominantnim i konstantnim vrstama, određujući na taj način floru i vegetaciju ovih površina. Među ovim vrstama posebno se ističu A. fruticosa i A. syriaca. Negativan utjecaj koji spomenute vrste ostvaruju opisan je u brojnim 
studijima (Tucovići dr. 2004.a, 2004.b, Radulović i dr. 2008., Porté i dr. 2011., Petrović i dr. 2013.) te je od izuzetne važnosti pratiti i kontrolirati njihovo stanje, kako bi se na vrijeme moglo djelovati.

\section{ZAKLJUČCI CONCLUSIONS}

Obrenovački Zabran je jedan od značajnijih lokaliteta u neposrednom savskom priobalju s gledišta očuvanja bioraznolikosti i područne raznolikosti, unapređenja kvalitete životne sredine i očuvanja kulturnih obilježja Beograda i njegove okolice. Obrenovački Zabran sačuvan je u najvećoj mjeri od potrebe za dobivanjem obradivih površina, što je u okruženju gdje su isušivana vodena staništa imala za posljedicu smanjenje bioraznolikosti. Prostor Zabrana je u bioekološkom smislu značajan kao stanište biljnog i životinjskog svijeta i doprinosi očuvanju geološke, biološke i područne raznolikosti.

Svjetlost i temperatura su ekološki čimbenici koji posebno pogoduju razvoju i širenju invazivnih biljaka u Obrenovačkom Zabranu, koje su najizraženije u području nasipa. Zbog toga i zbog izraženog antropogenog utjecaja, tj. velike frekvencije korisnika, invazivne vrste biljaka unešene su i prisutne na području Zabrana. Kako se istraživano područje nalazi pod zaštitom kao spomenik prirode, nedopustivo je daljnje širenje postojećih, ali i unošenje novih alohtonih, a posebno invazivnih vrsta. Samo pažljivo i odgovorno upravljanje prirodnim dobrom omogućit će da se njihov broj održi na postojećoj razini. Daljnje uređenje i unaprjeđenje treba ići isključivo u smjeru očuvanja i zaštite postojeće autohtone flore i vegetacije te obveznog praćenja dinamike i stanja postojećih invazivnih vrsta.

\section{ZAHVALA}

\section{ACKNOWLEDGMENT}

Ovaj rad realiziran je u okviru projekata „Istraživanje klimatskih promjena na životnu sredinu: praćenje utjecaja, adaptacija i ublažavanje” (43007) i „Ontogenetska karakterizacija filogenije bioraznovrsnosti” (173038) koje financira Ministarstvo prosvjete, nauke i tehnološkog razvoja Republike Srbije.

\section{LITERATURA} REFERENCES

- Boršić, I., M. Milović, I. Dujmović, S. Bogdanović, P. Cigić, I. Rešetnik, T. Nikolić, B. Mitić, 2008: Preliminary check-list of invasive alien plant species in Croatia. Nat. Croat. 17 (2): 55-71.

- Braun-Blanquet, J., 1964: Pflanzensoziologie. Grundzüge die Vegetationskunde, Springer Verlag, 865 p., Wien-New York.

- CPS SKEW: Schwarze Liste und Watch-Liste. Invasive gebietsfremde Pflanzen, http://www.cps-skew.ch/ (posjećeno: kolovoza 2015).
- Dawe, R. S., C. M. Green, T. M. MacLeod, J. Ferguson, 1996: Daisy, dandelion and thistle contact allergy in the photosensitivity dermatitis and actinic reticuloid syndrome. Contact Dermatitis 35: 109-110.

- Delivering Alien Invasive Species Inventories for Europe. European Invasive Alien Species Gateway, http://www.europe-aliens. org/ (posjećeno: kolovoza 2015).

- Di Castri, F., A. J. Hansen, M. Debussche, 1990: Biological Invasions in Europe and the Mediterranean Basin, Kluwer Academic Publishers, 480 p., Dordrecht.

- Di Tomaso, J. M., 2004: Weeds that cause dermatitis. Proc. Calif. Weed Sci. Soc. 56: 98-104.

- Drake, J., H. A. Mooney, F. Di Castri, R. Groves, F. J. Kruger, M. Rejmánek, M. Williamson, 1989: Biological Invasions: A Global Perspective, John Wiley \& Sons, 525 p., Chichester.

- Elton, C. S., 1958: The Ecology of Invasions by Animals and Plants, Methuen, 181 p., London.

- Global Invasive Species Database, http://www.issg.org/database/ (posjećeno: kolovoza 2015).

- Godefroid, S., N. Koedam, 2007: Urban plant species patterns are highly driven by density and function of built-up areas. Landsc. Ecol. 22: 1227-1239.

- Hennekens, S., J. Schaminée, 2001: TURBOVEG, a comprehensive data base management system for vegetation data. J. Veg. Sci. 12: 589-591.

- Igić, R., (ur.) 2012: Alergijske biljke, Odsjek za biologiju i ekologiju, Sveučilište u Novom Sadu - Prirodoslovno-matematički fakultet, 388 p., Novi Sad.

- IUCN, 2011: Another Milestone Towards 2010: Will Europe Win the Battle Against Invasive Species?, http://www.countdown2010.net/article/another-milestone-towards-2010-willeurope-win-the-battle-against-invasive-species (posjećeno: kolovoza 2015).

- Janjić, V., Lj. Radivojević, V. Jovanović, 2011: Common ragweed (Ambrosia artemisiifolia L.) - a harmful weed, ruderal and allergenic plant in the territory of Belgrade. Acta biol. iugosl. - ser. G: Acta herb. 20 (2): 57-67.

- Jávorka, S., V. Csapody, 1934: Iconographia Florae Hungaricae, Akadémiai Kiadó, 576 p., Budapest.

- Josifović, M., L. Stjepanović, M. Kojić, N. Diklić, (ur.) 19701986: Flora SR Srbije. 1-9, Srpska akademija znanosti i umjetnosti, Beograd.

- Jovanović, M., M. Poljački, N. Mimica-Dukić, P. Boža, Lj. Vujanović, V. Đuran, S. Stojanović, 2004: Esquiterpene lactone mix patch testing supplemented with dandelion extract in patients with allergic contact dermatitis, atopic dermatitis and non-allergic chronic inflammatory skin diseases. Contact Dermatitis 51 (3): 101-110.

- Kaufman, S. R., W. Kaufman, 2007: Invasive Plants: A Guide to Identification, Impacts, and Control of Common North American Species, Stackpole Books, 458 p., Mechanicsburg.

- Kojić, M., 1990: Livadske biljke, Naučna knjiga, 248 p., Beograd.

- Kowarik, I., 1995: Clonal growth in Ailanthus altissima on a natural site in West Virginia. J. Veg. Sci. 6: 853-856.

- Krstić, D., 2011: Stanje šuma Obrenovačkog Zabrana sa aspekta rekreativnog korišćenja, Diplomski rad, Sveučilište u Beogradu - Šumarski fakultet, 45 p., Beograd.

- Lakušić, D., 1993: Visokoplaninska flora Kopaonika - ekološkofitogeografska studija, Magisterij, Prirodoslovno-matematički fakultet, Sveučilište u Beogradu, 222 p., Beograd. 
- Lakušić, D., J. Blaženčić, V. Ranđelović, B. Butorac, S. Vukojičić, B. Zlatković, S. Jovanović, J. Šinžar-Sekulić, D. Žukovec, I. Ćalić, D. Pavićević, 2005: Staništa Srbije - priručnik sa opisima i osnovnim podacima, Biološki fakultet, Sveučilište u Beogradu, Ministarstvo za nauku i zaštitu životne sredine Republike Srbije, 684 p., Beograd.

- Lazarević, P., V. Stojanović, I. Jelić, R. Perić, B. Krsteski, R. Ajtić, N. Sekulić, S. Branković, G. Sekulić, V. Bjedov, 2012: Preliminarni spisak invazivnih vrsta u Republici Srbiji sa opštim merama kontrole i suzbijanja kao potpora budućim zakonskim aktima. Zaštita prirode 62 (1): 5-33.

- Mark, K. A., R. Brancaccio, N. A. Soter, D. E. Cohen, 1999: Allergic contact and photoallergic contact dermatitis to plant and pesticide allergens. Arch. Dermatol. 135: 67-70.

- McCune, B., M. J. Mefford, 1999: PC-ORD, Multivariate Analysis of Ecological Data, Version 5.0 for Windows, MM Software Design, Gleneden Beach, OR.

- Obratov-Petković, D., I. Bjedov, B. Jurišić, M. Đukić, D. Đunisijević-Bojović, D. Skočajić, M. Grbić, 2013: Influence of some environmental factors on the distribution of the invasive species Aster lanceolatus Willd. in various Serbian habitats. Fresen. Environ. Bull. 22 (6): 1677-1688.

- Oksanen, J., G. F. Blanchet, R. Kindt, P. Legendre, P. R. Minchin, R. B. O’Hara, G. L. Simpson, 2013: Vegan: Community Ecology Package, R Package Version 2.0-3.

- Paulsen, E., J. Soogaard, K. E. Andersen, 1998: Occupational dermatitis in Danish gardeners and greenhouse workers (III), Compositae related symptoms. Contact Dermatitis 38: 140-146.

- Petrović, J., N. Stavretović, S. Curčić, I. Jelić, B. Mijović, 2013: Invazivne biljne vrste i trčci i mravi kao potencijal njihove biološke kontrole na primjeru Spomenika prirode „Bojčinska šuma“. Šumar. list 1-2: 61-69.

- Porté, A. J., L. J. Lamarque, C. J. Lortie, R. Michalet, S. Delzon, 2011: Invasive Acer negundo out performs native species in nonlimiting resource environments due to its higher phenotypic plasticity. BMC Ecol. 11: 28.

- Radulović, S., D. Skočajić, I. Bjedov, D. Đunisijević-Bojović, 2008: Amorpha fruticosa L. on wet sites in Belgrade. Bull. Fac. Forest. Belgrade 97: 221-234.

- Stavretović, N., 2002: Struktura travnjaka kao determinator kvaliteta u različitim tipovima travnih površina urbanog područja Beograda, Disertacija, Šumarski fakultet, Sveučilište u Beogradu, 181 p., Beograd.

- Stavretović, N., 2008: Kvalitetne vrste i korovi u travnjacima urbanog područja. Monografija, Unija bioloških naučnih društava Srbije, 204 p., Beograd.
- Stavretović, N., J. Stevanović, A. Mijović, 2010: Invazivne biljne vrste na travnim površinama stambenih naselja Beograda. Acta biol. iugosl. - ser. G: Acta herb. 19 (1): 39-47.

- Stevanović, J., N. Stavretović, D. Obratov-Petković, A. Mijović, 2009: Invazivne biljne vrste na nekim sportsko-rekreativnim površinama Beograda. Acta biol. iugosl. - ser. G: Acta herb. 18 (2): 115-125.

- Stevanović, V., 1995: Biogeografska podela teritorije Jugoslavije. U Stevanović, V., V. Vasić (ur.): Biodiverzitet Jugoslavije sa pregledom vrsta od međunarodnog značaja. Biološki fakultet Sveučilišta u Beogradu i Ecolibri, 117-127. Beograd.

- Studij zaštite, 2011: Spomenik prirode „Obrenovački Zabran“, Zavod za zaštitu prirode Srbije, 97 p., Beograd.

- Šarić, T., 1991: Atlas korova, Svjetlost, 221 p., Sarajevo.

- Šilc, U., S. Vrbničanin, D. Božić, A. Čarni, Z. Dajić-Stevanović, 2012: Alien plant species and factors of invasiveness of anthropogenic vegetation in the Northwestern Balkans - a phytosociological approach. Cent. Eur. J. Biol. 7 (4): 720-730.

- Tichý, L., 2002: JUICE, software for vegetation classification. J. Veg. Sci. 13: 451-453.

- Tichý, L., M. Chytrý, M. Hájek, S. Talbot, Z. Botta-Dukát, 2010: OptimClass: using species-to-cluster fidelity to determine the optimal partition in classification of ecological communities. J. Veg. Sci. 21: 287-299.

- Tomić, Z., 1986: Vegetacija - prilog. Studija o stanju postojeće šumske vegetacije i Projekat uređenja park šume Obrenovački Zabran, Šumarski fakultet Sveučilišta u Beogradu i Institut za šumarstvo u Beogradu, Beograd.

- Tucović, A., V. Isajev, M. Šijačić-Nikolić, 2004a: Sekundarni areal i ekofiziološke karakteristike Amorpha fruticosa L. u Srbiji. Bull. Fac. Forest. Belgrade 89: 223-230.

- Tucović, A., V. Isajev, M. Šijačić-Nikolić, D. Vilotić, 2004b: Causes of amorpha (Amorpha fruticosa L.) invasion of forest sites in Serbia. Acta biol. iugosl. - ser. G: Acta herb. 13 (1): 1926.

- Tutin, T. G., V. H. Heywood, N. A. Burges, D. M. Moore, D. H. Valentine, S. M. Walters, D. A. Webb, (ur.) 1964-1980: Flora Europaea I-V, Cambridge University Press, 2392 p., Cambridge.

- Vrbničanin, S., B. Karadžić, Z. Dajić-Stevanović, 2004: Adventivne i invazivne korovske vrste na području Srbije. Acta biol. iugosl. - ser. G: Acta herb. 13 (1): 1-12.

- Witting, R., 2004: The origin and development of the urban flora of Central Europe. Urban Ecosyst. 7: 323-339.

- Zakon o zaštiti prirode Srbije („Službeni glasnik RS“, br. 36/09, $88 / 10,91 / 10)$.

\section{Summary}

The main aim of the conducted research was to determine the presence of invasive plant species in the protected natural area of the Obrenovački Zabran Nature Monument (Central Serbia). Floristic and vegetation study of the forest Obrenovački Zabran was conducted through several vegetation periods (from March 2009 to November 2013). The presence of 163 plant species recorded in the area of the Zabran Forest reflects its flora richness. Out of the total number of recorded species, 24 taxa are listed as invasive plant species, which makes $14.72 \%$ of the total flora of the Obrenovački Zabran Forest Nature Monument. Among them, there are six woody plant species and 18 herbaceous plant species. Along the whole embankment track, the species Asclepias syriaca and Amorpha fruticosa were registered with a high value of the measured parameters each. 
These two species create a wood edge leading down to the Sava River and suppress almost all other plants of the shrub floor, with a tendency to suppress already sparse vegetation of the ground floor. The most important environmental factors influencing the development and spreading of invasive plants in Obrenovački Zabran are light and temperature, which are most pronounced in the embankment area. Also, a strong anthropogenic influence, i.e., high frequency of users, has led to introduction and presence of invasive plant species in the area. The greatest number of determined invasive plant species belong to the family Asteraceae (nine species), then to the families Fabaceae and Poaceae (with two species each), whereas the other families had a single invasive species each.

Research results should provide a basis for development of strategies for monitoring the state of unwanted species and planning measures of their reduction in order to protect the autochthonous flora. Only careful and responsible management of the natural area would maintain the abundance of these species at the current level.

KEY WORDS: Sava River, Obrenovački Zabran, invasive species, environment protection, nature protection

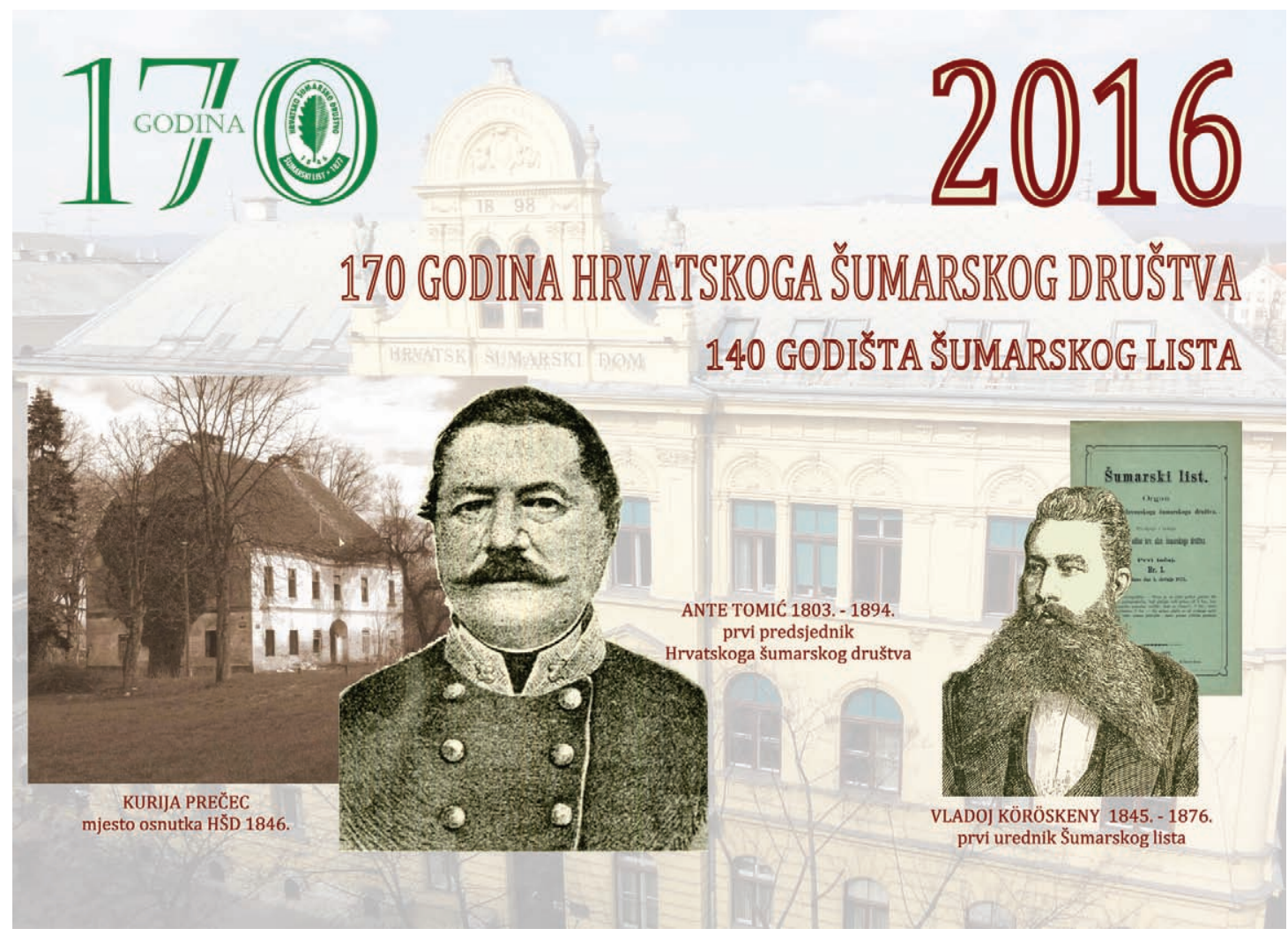

